\title{
THE DIRECTIONS OF MOVEMENT FOR SOCIALISM (MAS) IN BOLIVIA: THE DIALOGUE BETWEEN FOREIGN POLICY AND DIPLOMACY
}

\begin{abstract}
NATALIA CEPPI
natalia.ceppi@fcpolit.unr.edu.ar $\mathrm{PhD}$ in International Relations from the National University of Rosario (Argentina). Master in Integration and International Cooperation (CEI-CERIR-UNR). Degree in International Relations (UNR). Deputy Researcher at the National Council for Scientific and Technical Research (CONICET). Professor of Consular and Diplomatic Law, Bachelor's Degree in International Relations, Faculty of Politics and International Relations (UNR).
\end{abstract}

\begin{abstract}
Foreign policy and diplomacy are, within the framework of International Relations studies in general, two categories that enjoy great prominence. In practical terms, they have a close, symbiotic bond and even the idea persists that both mean the same thing. However, from a theoretical-conceptual perspective, foreign policy broadly implies the objectives of the state at the international level, while diplomacy reflects the means to achieve them. Based on this, this paper seeks to identify and reflect on the central axes that crossed the dynamics of Foreign Policy and Diplomacy of Bolivia during the three governments of Evo Morales (20062019). Likewise, a brief projection is made on this very particular binomial after the return of MAS to power, following the triumph of Luis Arce and David Choquehuanca on October 18, 2020.
\end{abstract}

\section{Keywords}

Bolivia, MAS, foreign policy, diplomacy, change/continuity

\section{How to cite this article}

Ceppi, Natalia (2021). The directions of movement for socialism (mas) in Bolivia: The dialogue between foreign policy and diplomacy. Janus.net, e-journal of international relations. Vol12, No. 2, November 2021-April 2022. Consulted [online] on the date of the last visit, https://doi.org/10.26619/1647-7251.12.2.3

Article received on January 26, 202 and accepted for publication on March 24, 2021

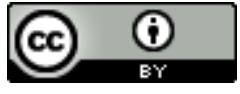




\title{
THE DIRECTIONS OF MOVEMENT FOR SOCIALISM (MAS) IN BOLIVIA: THE DIALOGUE BETWEEN FOREIGN POLICY AND DIPLOMACY1, 2
}

\author{
NATALIA CEPPI
}

\section{Introduction}

The arrival of MAS to the presidency of the Plurinational State of Bolivia, after its first presidential victory on December 18,2005 , constituted a fact of great impact beyond its implications in the national reality. At the regional and extra-regional levels, the media, academics, and policymakers closely followed the rise of the Evo Morales-Álvaro García Linera formula. Such an expectation can be understood, among other things, from the development of the electoral contest itself. In the collective imaginary, the 2005 elections were not seen as just another suffrage, that is, as part of the intrinsic practice of the democratic game, since these, for the first time since 1985, offered reliable possibilities to put an end to the coalition governments that constituted the period of the so-called Pacted Democracy ${ }^{3}$.

In this context, the triumph of MAS was an unprecedented event for several reasons. In the first place, its access to power was given through obtaining an absolute majority of the votes (53.74\%), which had not happened since 1982. Secondly, MAS differed from traditional political parties by being a political movement that represented and, at the same time, articulated indigenous, peasant and trade union demands, whose identity components were wielded around the strong leadership of Evo Morales (Mayorga, 2008, 2016). Thirdly, its government program was focused on the process of Refounding the State, which, broadly speaking, implied disruptive policies not only at the domestic level, but particularly in the external agenda and in the international linkage of the country. For MAS, it was imperative to provide foreign policy and diplomacy with new contents and structures by understanding them as the reflection of national identity, but also because they would allow the satisfaction of certain political and economic interests.

Article translated by Hugo Alves.

The present work continues and deepens some lines of analysis that have been developed in previous research instances within the framework of the National Research Council Scientific and Techniques (CONICET).

3 Exeni Rodriguez (2016: 84-85) maintains that Agreed Democracy is "taxation" of the Pact for Democracy as a post-electoral event of the 1985 elections where the Presidential election fell to Congress in the absence of an absolute majority. By tradition, the first majority was ratified, but on that occasion, Hugo Banzer Suárez, a former de facto president, and DNA candidate, was displaced by Víctor Paz Estenssoro of the MNR. with the backing of his party and other forces Legislative. Two months later, ADN supported the Executive in parliament, and they signed a governance pact. From there, the traditional parties (MNR, ADN and MIR) were rotating in power thanks to the alliances made in the Legislative together with other minor forces. 
This paper proposes to reflect on the central aspects that have marked the compass of Bolivia's foreign policy and diplomacy during the three administrations of Evo Morales (2006-2019). It also seeks to infer possible modes of action in the matter with respect to the recent mandate of Luis Arce and David Choquehuanca, whose triumph in the elections of October 18, 2020, gave way to the return of MAS to the executive branch after the interim government of Jeanine Áñez. It is argued as a conjecture that, under the leadership of Morales, the foreign policy and diplomatic actions of the Andean country have been disruptive and marked by a rhetoric with a strong ideological component, especially when compared to the governments that preceded MAS. In both cases, there is a clear commitment to pragmatism to conquer and benefit from the political and economic possibilities of the context, whether in the framework of bilateral relations or in multilateral instances.

For the purposes of this study, a qualitative methodological design has been used with a view to comprehensively characterize the core of the analysis. Being flexible and having a holistic perspective, it approaches the object of study from the idea of unity, that is, as a whole - and not as a sum of parts - so the focus is on the phenomenon and its context (Taylor and Bogdan, 1987; Sautu, 2005; Hernández Sampieri, Fernández Collado and Baptista Lucio, 2014). On the other hand, the empirical references come from official documents, national regulations and specialized articles on the different edges that are part of the research, using bibliographic and documentary searches as techniques for collecting information.

In organizational terms, the analysis is presented in three sections. In the first one, a brief presentation is made on the MAS government proposal at the domestic level and then establish its connection regarding the external actions of the country. It should be noted that the stay of MAS in the presidency of Bolivia throughout three consecutive administrations aroused curiosity and interest on the academy, whose production has put under the spotlight multiple aspects and dimensions that have been part of the government plans of Evo Morales, both domestically and externally. In general, at the domestic level, studies focused mainly on the relationship of MAS with social movements, the territorial advance of the ruling party versus the decline of the opposition; the demands of the indigenous-peasant collective and its proposal for change in the link between the state, society, and market forces. Regarding the country's external actions, much of the analysis has focused on the transformations that have been established since 2006 in the central guidelines and basic guiding principles of foreign policy, the agenda items and in the regional and extra-regional links of an actor with little room for maneuver in the international context (Fernández Saavedra, 2011; Canelas and Verdes Montenegro, 2011; Trejos Rosero, 2012; Namihas, 2013; Olmos Castro, 2014; Ceppi, 2015, 2019; Querejazu Escobari, 2015; Souza, Cunha Filho and Santos, 2020; Ponce Costa, 2020, etc.). This has had as a correlate, the enrichment of academic debates and, at the same time, has contributed to strengthen the analysis of this process based on two central notions in the international activity of states, such as foreign policy and diplomacy. Both categories have a close relationship and great coupling, and it is common that they are usually used as synonyms. However, for International Relations and Diplomatic Law, they conceptually comprise different notions (Pérez Manzano, 1989; Moreno Pino, 2001, Arredondo, 2016; Vilariño Pintos, 2016; Hocking, 2016). Foreign policy represents the objectives and goals of the state in its international actions, while 
diplomacy is an instrument - always peaceful - for the achievement of them (Arredondo, 2016: 8-10).

The second section identifies the most relevant aspects that have given content to the foreign policy and diplomacy of the Morales governments. Bearing in mind that in the foreign policy/diplomacy distinction, the former deals with the what (what goals or objectives) and the latter with the how (the means or tools), the most significant objectives of the period 2006-2019 are analyzed with their corresponding implementation policies. The decision to approach them in a distinctive way - in conceptual terms, but at the same time as a unit - contributes to deepen the theoretical analysis of each category. At the same time, their treatment together makes it possible to have a sort of snapshot; a more complete picture of the situation on the positions, decisions, and actions of policymakers at the international level, considering the domestic and systemic situations.

Finally, in the third section, which works as a closing one, some aspects related to the conduct that Luis Arce and David Choquehuanca intend - at least from the rhetoric - to print to the foreign policy and diplomacy of the Andean country are outlined tentatively.

\section{The starting point}

The arrival of Evo Morales and Álvaro García Linera to the presidency can be synthetically contextualized in a scenario that combined countless elements, many of them, opposed to one another: great expectations, in particular, on the part of the indigenous-peasant collective, political-institutional instability, and enormous challenges at the socio-political and economic levels. The promises of growth, development, and well-being of the governments of the Pacted Democracy - anchored in the implementation of orthodox economic programs - lacked correlation in the actions. At the beginning of this century, recession, poverty, and inequality had become a profound structural problem and, consequently, the leitmotiv of the demands for change versus continuity of a large part of the population ${ }^{4}$. Popular discontent was channeled into events such as the Water War (2000), the Gas War (2003), the resignation of Gonzalo Sánchez de Lozada in October 2003 and multiple citizen and peasant protests that had social movements as main protagonists. Those made more evident not only the erosion of the traditional political parties, but also a determining factor in the triumph of MAS. According to Zuazo (2010), MAS has resulted from the expansion of democracy during 1982-2000 but, at the same time, it has been a consequence of its deep crisis. It was born by the decision of the peasant social organizations to have a political instrument, which was later extended to the cities, generating because of its triumph in 2005 the transition to an "urban party", with an overwhelming leadership of Morales as President and head of the party.

For MAS, the two decades of Pacted Democracy had generated a weak, porous state, whose roles and functions were restricted to favor transnational capital and the conservative groups that had traditionally governed the country (MAS-IPSP Government Program, 2005: 10). Faced with this, Evo Morales understood that the refoundation of

4 According to Bolivia's Social and Economic Policy Analysis Unit (UDAPE), in 2000, moderate poverty reached $66.4 \%$ of the population; extreme poverty accounted for $45.3 \%$ and the Gini Coefficient was 0.66 . Statistics 
the social pact required the existence of a state that had a strong presence in the domestic sphere and in the external agenda to establish multidimensional changes, in accordance with his campaign proposal. The guiding principles of action - which were subsequently renewed in the following mandates - were presented in the National Development Plan of 2006, as a comprehensive strategy, aimed at the construction of a Dignified, Democratic, Productive and Sovereign Bolivia to Live Well (National Development Plan, 2006). In general, it implied the implementation of measures aimed at redefining the state-market and state-society link, rescuing, and incorporating the worldview of the peasant indigenous peoples. For its part, Vivir Bien ${ }^{5}$ is a philosophy, an ancestral paradigm conceived in interculturality; "an alternative civilizational and cultural horizon to capitalism and modernity", which is understood and achieved practically and collectively by integrating the social, cultural, political, environmental, and economic dimensions (Ministry of Foreign Affairs of Bolivia, 2014: 60).

In fact, MAS proposal for changing has rested on the construction of an active state - in this case, in its plurinational version - (Cordero Ponce, 2012), based on the ideals of national development, social reformism and more inclusive forms of participation and representation. At the domestic level, this process has been cemented through:

a) The nationalizations and renegotiations of contracts in strategic sectors, such as hydrocarbons (Supreme Decree 28, 701, 2006), mining [Huanuni, the most important tin mine in the country (2006)], telecommunications [ENTEL company (2006)], metallurgy [Vinto company (2007)], fuel [Air BP (2009)], electricity [Corani, Guarachi, Valle Hermoso and the electricity distributor of Cochabamba (2010)], smelting [the Vinto antimony plant (2010)], and airport services [SABSA (2013)(CELAG, 2019)];

(b) The promulgation of a new National Constitution (2009), which, among other things, is based on the expansion of citizenship rights with the recognition of the rights of indigenous peasant communities, such as autonomies, intercultural democracy, and the formation of Bolivia as a plurinational state (Cordero Ponce, 2012);

(c) Commitment to the fight against poverty and inequality through the development of conditional cash transfer programs in health, education, the elderly, and pregnancy. At the end of Morales' third term, in $2018,51.2 \%$ of the total population was a beneficiary of some social bonus (Ministry of Economy and Public Finance of Bolivia, 2019). This generated a virtuous circle with respect to social indicators since poverty - both moderate and extreme - and inequality had a clear downward behavior in the period $2005-2018$. Moderate poverty went from $60.6 \%$ to $34.6 \%$; the extreme kind from $38.2 \%$ to $15.2 \%$ and the Gini Coefficient from 0.60 to 0.46 (Ministry of Economy and Public Finance of Bolivia, 2019: 196-197).

However, for the Refoundation of the State to be understood in a comprehensive and conclusive way - "total refoundation", according to the MAS position - the foreign policy, diplomacy and international relations of the country must, by extension, have differentiating features from the governments of the Pacted Democracy.

5 On the analysis of Vivir Bien in Bolivia, it is recommended to consult Martínez (2016). 
Now, what is meant by foreign policy and diplomacy? Returning to the initial proposal of this work, where these categories are observed in terms of unity, but at the same time they are conceptually differentiated, foreign policy comprises, following the ideas of Hermann (1990), a program - a plan that is elaborated from the executive power for the achievement of goals to be accomplished at the international level. In this sense, foreign policy, as stated by Wilhelmy (1991), Lasagna (1996), Milani and Pinheiro (2013), Busso (2016, 2019) and Míguez (2017, 2020), among others, is inscribed as public policy, that is, as the set of objectives and actions carried out by a government in the face of problems - or could be added, issues in general - that at a certain moment arouse interest on the part of the government itself as well as other actors, among them, the citizens (Tamayo Sáez, 1997). This implies, according to the analysis of Oszlak and O'Donnell (1976), a position taken by the state, which is concretized in decisions that are not necessarily expressed in formal acts, aimed at resolving that question that arises. Being a mode of intervention where the decisions or perspectives of various actors are included, this "position taking does not have to be univocal, homogeneous or permanent" (Oszlak and O'Donnell, 1976: 21). This results in three important elements to take into account: 1 - that predominant position that concerns other sectors of society, develops in a specific historical context and moment; 2- when several actors coexist in the fixation of the position, sometimes, the decisions can be contradictory and/or conflictive and 3the taking of position can be active or by omission, both being a way of dealing with the agenda item (Oszlak and O'Donnell, 1976: 21-23).

The particularity of foreign policy lies in the fact that when the state adopts positions in the face of problems of interest, a constant interaction between the domestic and external planes is observed (Busso, 2019, Míguez, 2020). In the words of Wilhelmy (1991: 177), the specificity of the international problem generates that foreign policy objectives are identified from the incidence of the influences that come from the political system, domestic considerations of politics and from the significance of the actors and the international environment.

Therefore, while foreign policy sets and decides the guidelines for action - mediate or immediate - by a state, diplomacy is a way of executing, always peacefully, that foreign policy (objectives and agenda items) that has previously been decided. That said, diplomacy is essentially a tool or an instrument at the service of foreign policy (Vilariño Pintos, 2016: 75). For Vilariño Pintos (2016: 75-76),"diplomacy is not an end, but a means; not a purpose, but a method". This implies understanding, according to the author, that foreign policy has a substantive character and diplomacy an adjective character, generating that they are - according to the neologism he uses - of an order that is "completive", since diplomacy does not have an existence separate from foreign policy.

Considering that in the construction of the objectives and agenda items that mobilize the international action of the states, there are factors of a domestic and systematic order, foreign policy, in its condition of public policy, is not something static or unalterable. On the contrary, the coexistence between change and continuity is a recurring pattern when it is put under analysis. In this sense, the foreign policy of MAS is no exception, since throughout the three administrations of Morales, in terms of Lasagna (1995), the presence of traditional and contingent criteria emerges. The former alludes to aspects or 
guidelines that are part of the assembly of a country's foreign policy, regardless of changes in government; being in the case study, the defense of democracy, sovereignty, and human rights; non-interference in the internal affairs of other states, the peaceful resolution of conflicts and the claim for sovereign access to the sea in the face of their dispute with Chile. On the other hand, the latter responds to conjunctural questions by understanding the inclinations or preferences of the government of the day and the "inputs it receives from abroad" (Lasagna, 1995: 390-391). When applied to Bolivian foreign policy, the contingent criteria are unfailingly associated with the process of Refoundation of the State; the idea of rupture and the need to establish a paradigm shift in international relations. According to the Ministry of Foreign Affairs, the governments that preceded MAS shared a foreign policy whose objectives were marked by the politicalideological dependence of the United States of America, the fulfillment of the orthodox postulates of the international financial organizations and the obtaining of benefits for the ruling elites and the business sector (Ministry of Foreign Affairs of Bolivia, 2014). Faced with this, the Morales administration set out to provide foreign policy with a new doctrinal structure in accordance with the redefinition of the state's ties with the market and society and the principles held in partisan terms.

In discursive terms, the former president opted for a rhetoric that was more radical than moderate, with a marked counter-hegemonic stance, very critical of capitalism in general and neoliberalism and a defender of Vivir Bien and the principles upheld by the indigenous peasant collective. This was reflected in the habitual use of the idea of "us-others" within the United Nations. Consequently, the "we" (the indigenous, peasants and social movements; the developing countries victims of capitalism and colonialism and the governments that seek a more just and equitable world) and the "others" [the procapitalist countries - USA - transnational corporations and international financial organizations (Olmos Castro, 2014)], have had a leading place in the dichotomous worldview of Morales as a leader, but also in the design of foreign policy and the socalled People's Diplomacy ${ }^{6}$.

This new paradigm was the framework of Bolivian foreign policy between 2006 and 2019, which was especially focused on the treatment of the following macro-objectives: 1) the maritime claim, 2) the establishment of complementary, diversified and less asymmetric external relations and 3) the revaluation of national identity. Next, each of them was developed, also considering the diplomatic actions - as tools - that were implemented with a view to concretizing them. As Wilhelmy (1991: 179-180) puts it, the instrument - in this case, diplomacy - is at the service of the objective and "a repertoire of instruments must be adapted to each constellation of interests and objectives; the calculation of this adequacy constitutes one of the central tasks of the governmental actor in foreign policy".

6 According to MAS, the "Diplomacy of the Peoples" is based on "Living Well" as a philosophical paradigm of the Andean indigenous peoples and it can be understood as one of the pillars of the foreign policy of the period, being this one in charge of fulfilling the established management objectives. It is clear from the official documents that it is a new way of carrying out a foreign policy whose principles, objectives, and interests, differ widely with the past. Its central characteristics are the broadening of the idea of international relations, that is, there is talk of linkage not only between states, but between peoples and/or nations; social movements have an important role, especially in political forums; promotion participatory democracy and the construction of solidary, complementary, and cooperative relations (Ministry of Foreign Affairs of Bolivia, 2014: 111-112). 


\subsection{Maritime demand vis-à-vis Chile}

Unlike the other objectives of the external agenda, the demand for sovereign access to the Pacific Ocean has been a constant in Bolivian foreign policy beyond the changes of government. Since the signing of the Treaty of Peace and Friendship in 1904, contacts with Chile have gone through various conflictive situations - including the rupture of diplomatic relations in 1978 - in the face of the existence of diametrically opposed positions: for Chile, the territorial issues were settled at the beginning of the $20^{\text {th }}$ century, while, for Bolivia, sovereign access to the sea still constitutes a pending claim.

Seeking to obtain some kind of progress in the matter, Evo Morales bet on the dialogue with the first government of Michelle Bachelet (2006-2010) and both agreed on the need to renew the spirit of the bond between the two countries by signing the Agenda of the 13 points or "agenda without exclusions", where the treatment of the maritime issue was incorporated. At that time, diplomatic efforts were concentrated at the bilateral level with the aim of improving the quality of interstate dialogue and from there delving into the possibility of finding a "face-to-face" agreement on the matter (CorreaVera and García Pinzón, 2013: 96). The meetings between Bolivian and Chilean officials were held annually and were in line with the process of rebuilding trust proposed by the then presidents. However, with the beginning of the government of Sebastian Pinera (20102014), the dialogue between the foreign ministries of Bolivia and Chile was gradually set aside, with crossed accusations about the responsibility of what happened, evidencing that the talks could never overcome the formal aspect due to the lack of mobility in the position traditionally held by each actor.

Towards this situation, Morales decided to establish changes in the actions of diplomacy in face of this historical claim. The first measure was presented in the creation of the Strategic Directorate of Maritime Reclamation (DIREMAR) within the ministry of foreign affairs, assigning it the tasks of planning, developing, and implementing everything related to the maritime issue. The second measure was reflected in the judicialization of the lawsuit before the International Court of Justice (ICJ) on April 24, 2013, under the American Treaty of Peaceful Solutions of 1948, known as the Pact of Bogotá (International Court of Justice, 2013). However, the turn in tactics (diplomatic action) was not only evident in the abandonment of the bilateral level, but also in the axis of the claim since the demand did not focus on the direct denunciation of the Treaty of 1904 as had happened other times - but on the alleged breach by Chile in its obligation to negotiate a sovereign exit to the Pacific. For the Bolivian foreign ministry, this obligation was based on a set of events, such as unilateral declarations, diplomatic exchanges, bilateral agreements and diplomatic declarations and interactions within the framework of the Organization of American States (OAS), which followed independently of the 1904 Treaty (International Court of Justice, 2013; Ceppi, 2019). Besides, Evo Morales took advantage of the opening sessions of the UN General Assembly to promote the Bolivian cause, raise its profile to the maximum and, at the same time, seek international support, appealing to issues such as Chile's lack of understanding in the face of a 'just and inalienable' claim; the importance of the peaceful settlement of disputes, especially 
between neighboring countries, and the recommendations made by world leaders for the two states to work on finding a solution for that conflict?

Once the written and oral phases established in the regulatory procedure were carried out, the ICJ issued its judgment - binding and unappealable to the parties - on October 1,2018 . By 12 votes in favor and 3 against, the international court completely dismissed the Bolivian lawsuit by rejecting each of the legal instruments on which Andean diplomacy had built its claim (International Court of Justice, 2018). Beyond the legal evaluations that may be carried out, the ICJ pronouncement implied, from the perspective of Bolivia's international relations, the end of the judicialization of the claim as a diplomatic action and, consequently, the need to rethink in the future new mechanisms for the treatment of this problem. As González Vega (2019: 86) summarizes, "the Court did not [see] in any of the documents, of the long payroll provided by Bolivia, nothing more than mere political commitments, unfeasible to establish a legal obligation in charge of Chile" (...) "The closure of the judicial procedure has meant a defeat - almost without palliatives for [Bolivia's] claims, given the tenor of the arguments developed by the Court. However, the disagreements between neighboring countries do not end with this" (González Vega (2019: 97).

\subsection{External relations: new approaches, new media?}

According to the ministry of foreign affairs of Bolivia (2014), Vivir Bien translates, among other issues, in the field of foreign policy, the construction of new forms of linkage based on cooperation, complementation and the reduction of asymmetries with a view to strengthening the regional and extra-regional positioning of the country. Seeking to get closer to this objective, Bolivian diplomacy provided different instruments at the multilateral and bilateral levels of the external agenda. At the multilateral level, regional integration occupied a prominent place throughout the three Morales administrations since "no country alone can meet its needs and solve its problems" (National Development Plan, 2006: 239). However, for MAS, traditional integration schemes, focused on economic-trade liberalization, such as the Andean Community of Nations (CAN) or the Southern Common Market (MERCOSUR), had as a critical point the lack of construction of a broader agenda that included addressing social, political, cultural, and environmental problems. Integration policies should have a 'holistic' perspective that would allow the development of relationships whose orientation rested on the principles mentioned above.

Faced with this new perspective, the schemes of cooperation and concertation that emerged in the light of the so-called "post-liberal regionalism" (da Motta and Ríos, 2007; Sanahuja, 2012), were the means through which the Bolivian government sought to channel much of its interests with Latin American peers regarding the political dimension. The dynamics of regionalism were not left out of the process of ascent that, from the present century, progressive governments had $^{8}$. They not only questioned the idea of

7 It is recommended to consult the speeches of the former president in the UN digital library. Available at https://digitallibrary.un.org/search?!n=es\&cc=Speeches

8 As Svampa expresses (2017), with this generic category covering different policy and ideological trends, it alludes to the change of era that crossed much of the South American continent between 2000 and 2015. 
open regionalism, that is, that regionalism that prevailed between 1990 and 2005, based mainly on trade where integration was directly associated with the liberal policies of the Washington Consensus, but also led to its redefinition (Sanahuja, 2012). Consequently, regionalism was thought in a post-liberal key, giving rise to structures such as the Bolivarian Alliance for the Peoples of Our America-Peoples Trade Treaty (ALBA-TCP), or the Union of South American Nations (UNASUR). Despite their specific features, they were characterized, in general, by attaching importance to political and social issues, appeal to South-South cooperation, reject orthodox economic policies and promote a state more present in the different dimensions of the national agenda (Sanahuja, 2012).

MAS found in these mechanisms, on the one hand, spaces for dialogue, sometimes more ideologized, as is the case of ALBA-TCP and, on the other hand, platforms for the generation of agreements of various kinds, as well as the minimization of conflicts (Agramont Lechín, 2010). Taking the ideas of Diamint (2013: 64), these schemes ${ }^{9}$, did not know the commercial plane; rather than that, they were conceived as primarily political and non-economic agreements, where the consequences of "political intertwining" extended to the economic field, contrary to the proposal offered by a process of classic trade liberalization. Bolivia's presence within the framework of ALBATCP is an example of this statement. The Andean country benefited from the sending of various social missions in the fields of health and education, that were supported by economic contributions (Venezuela) and human resources [Cuba (Ceppi, 2015]. It was also the recipient of donations, tariff reduction in trade agreements and reimbursable credits for infrastructure works (Vergara Toro, 2016). It should be noted that a large part of these funds was received directly from the Venezuelan embassy in La Paz, so the amount of money sent is not known exactly as the true destinations of the same (Vergara Toro, 2016: 77).

The promotion of an integration with a political nuance did not imply the loss of interest in traditional commercial schemes. Bolivia did not abandon the CAN and signed in 2012 - coinciding with the decline of ALBA - the protocol of accession to MERCOSUR as a member state, seeking to overcome its status as an associate ${ }^{10}$. In short, Morales leaned firmly towards multilateralism and integration, either in its "open regionalism" version where the economic prevails - or the " $21^{\text {st }}$ century version", typical of the progressive cycle that mostly passed through the South American space between 2000 and 2015. Consequently, about regionalism, MAS appealed to dual-member diplomacy, which contributed to diversifying the foreign policy agenda, strengthened Bolivia's visibility in the regional context and energized, in general terms, contact with peers, especially with those who were in the same ideological harmony.

At the bilateral level, diplomacy broadened the horizon of inter-state dialogue to reach agreements on various issues, some of them still old, others with a propositional character. The renegotiation of energy contracts with Argentina and Brazil after the nationalization of YPFB in 2006, the final border demarcation with Paraguay, product of the Chaco War in 2009; the signing of a supplementary protocol to the International Labour Organizaion Conventions (1992) in 2010 and then the ILO Declaration with Peru

9 In her work, the author focuses on ALBA-TCP and UNASUR.

10 This process has not yet materialized. 
in 2019; the renewal of memorandums of understanding with the EU on cooperation ${ }^{11}$; the establishment of diplomatic relations with Iran in 2007 and the updating of ties with China and Russia reflect the role of diplomacy as the executing arm of a diversified and pragmatic foreign policy (ministry of foreign affairs of Bolivia, 2014; announcement of the government of Peru, 2019).

At the extra-regional level, ties with China and the USA deserve special consideration. For its part, the Asian country had a vertiginous rise in the Bolivian external agenda thanks to trade complementarity - export of raw materials and import of value-added products - and the economic and political aid that has been framed as part of SouthSouth cooperation (Hedrich, 2016). Taking advantage of Morales' anti-imperialist and counter-hegemonic rhetoric, China has provided loans and investments and acquired large volumes of products such as lithium, silver, tin, lead, refined copper, quinoa, and sesame seeds, among others. However, being an asymmetrical link, the Chinese action is responsible for determining, according to its interests, in what and how to forge bilateral agreements. In this sense, in terms of results, the compromise with China which here is understood as a receptive diplomacy - would be far from fulfilling the objective of generating complementary and more balanced relations.

As for the link with the USA, the Morales government opted for a diplomacy of retreat. In the political arena, the relationship was characterized by tension and cooling. Ideological differences, especially during the Trump administration, rapprochement with Russia, China, and Iran; support for Venezuela; the expulsion in 2008 of the then USA ambassador, Philip Goldberg, accused of conspiring against the Morales government, and the suspension of the activities of the DEA and USAID in Bolivian territory, undermined the possibilities of building high-level contacts.

\subsection{Bolivian identity to the world}

Cultural diversity, as one of the basic features of the country, implied, at the level of the MAS foreign policy, the international promotion of a large part of the causes that make up the demands of the indigenous peasant collective. To this end, Bolivian diplomacy firmly bet on multilateral spaces, especially the UN, either by establishing a position on certain issues, or by taking the initiative with respect to the actions to be followed. In his years as president, Morales concentrated on:

(a) The defense and promotion of the rights of indigenous peoples (self-determination; the possibility of living in community; respect for customs and traditions; recognition of autonomy, etc.). Bolivia accompanied, together with other Latin American states, the initiative to have a declaration by the organization as a tool that would contribute to the process of reparation of those communities that were victims of the policies of colonialism. Finally, on 13 September 2007, the UN Declaration on the Rights of Indigenous Peoples was adopted by the general assembly with 144 votes in favour

11 Bolivia and the EU have been pursuing their relations since 1995 , especially in cooperation. It is the main recipient of EU bilateral development aid in Latin America, with a budget of 281 million euros for the period 2014-2020. Source: EU Delegation to Bolivia. In: https://eeas.europa.eu/delegations/bolivia/966/boliviay-la-ue es. 
and 4 against. In November of that same year, it acquired legal force in Bolivia when it was elevated to the rank of law.

b) The defense of the coca leaf as a symbol of Andean culture. According to Morales, the criminalization of the coca leaf constitutes a historical injustice by being directly associated with drug trafficking. "I mean it's the green coca leaf, not the white one. This coca leaf represents the Andean culture, the environment, and the hope of the peoples. It is not possible for the coca leaf to be legal for Coca-Cola and illegal for other types of medicinal consumption in our country and throughout the world" (Morales, 2006: 37). After several years of claims, the UN accepted in 2013 a reservation of the Andean country to the Convention on Narcotic Drugs of 1961, in which Bolivia is recognized the acullico (chewing of coca) as an ancestral practice, as well as the consumption of the coca leaf for cultural and medicinal purposes and its legal trade within the national territory ${ }^{12}$.

(c) Privatization of basic services. From the beginning of his administration, Morales launched a global campaign against the participation of private companies in the provision of services, including water. For MAS, they represent universal rights and not a commodity, so it is the competence of the states and not of the private sector to guarantee their access in a universal and equitable way ${ }^{13}$. At the $\mathrm{V}$ World Water Forum (2009), at the initiative of Bolivian diplomacy, 25 countries signed a declaration parallel to the official one, where access to water and sanitation were considered fundamental human rights (Justo, 2013). A year later, the Bolivian state bet more strongly on this request and requested - co-sponsored by 33 countries that the UN be promulgated in this regard. With 122 votes in favour and 41 abstentions, the general assembly recognized the right to safe drinking water and sanitation as essential human rights per se and for the enjoyment of other human rights.

(d) Natural resources and climate change. In 2007 Morales stated that, for the indigenous movement, land was a sacred issue and therefore could not be turned into a simple business or commodity. In this sense, the former president has been an active actor in the promotion of the rights of Mother Earth and respect for the bond between indigenous peasant communities and natural resources by maintaining that capitalism is the cause of the process of environmental degradation and social inequalities between and within countries. In the Bolivian case, this criticism translates, in part, into the need for the state to regain prominence in the extractive industries, seeking to reduce the asymmetries in terms of benefits compared to the private sector. This claim had, like the issue of water, reception at the UN. On the initiative of Andean diplomacy, April 22, 2009, was declared the International Day of Mother Earth (UN general assembly, 2009). However, it is worth mentioning that this issue, as the axis of public policy, has not been without tensions and contradictions. The intensive exploitation of raw materials, particularly minerals and hydrocarbons,

12 Consult Single Convention on Narcotic Drugs, 1961, as amended by the Protocol amending the Single $\begin{array}{llll}\text { Convention on } & \text { Narcotic } & \text { Drugs, } & 1961 . \\ \text { https://treaties.un.org/Pages/ViewDetails.aspx?src=TREATY\&mtdsg no=VI- }\end{array}$ $18 \&$ chapter $=6 \&$ clang=_en\#EndDec

13 Just (2013) affirms, based on the position of the constitutional court of the country, that the look antimercantilist it is a consequence of the events of the Water War in Cochabamba in 2000. 
has been one of the pillars on which MAS based its social and economic policies. In the first decade of this century, coinciding with the boom in commodity prices, Bolivia, like other South American neighbors, bet on mega-extractivism,"promoting indiscriminate exploitation (...) with export objectives (Svampa, 2019: 70). Ties with Argentina, Brazil and China are examples of such. This whole process has put in check the basic principles of "Living Well", among which the abandonment of unlimited growth is promoted as part of the development and promotion of a more sustainable and solidary economy. In parallel, it has generated numerous conflict situations with indigenous and peasant communities because of the expansion of extractive activity - or related projects - in their territories, being emblematic the case of the Indigenous Territory and Isiboro-Sécure National Park (TIPNIS) (Svampa, 2019).

Finally, two events that are results of diplomatic work with a view to fulfilling the revaluation of cultural identity as an objective stand out: the incorporation of the wiphala - symbol of identification of the peasant indigenous peoples - in the acts of state, together with the tricolor flag and, the curricular changes in the training granted by the Bolivian foreign ministry to its officials. As an example, there is the teaching of the Aymara language, the introduction of subjects such as decolonization and political doctrines and the participation of the main indigenous social organizations in the training carried out by the diplomatic academy (Ministry of Foreign Affairs of Bolivia, 2014).

\section{3. Áñez, the return of MAS and the memory of Morales}

Throughout his three administrations, Morales gave a hallmark to Bolivian foreign policy and diplomacy. As noted at the beginning of this work, both were disruptive, but especially pragmatic. Disruptive by the doctrinal scaffolding and sustained actions, especially contrasting them with the nineties; pragmatic, because they were designed in the search for political and economic functionality, sometimes more of a partisan nature than as a government program. All this generated that the country had a great exposure on the international stage, being understood as an unprecedented moment.

The wishes of a fourth term on the part of Morales and García Linera were truncated in the face of the high degree of conflict that the country was going through, product of the claims around the 2019 elections where the ruling party had obtained a new victory. Here converged issues such as social polarization - those who supported the victory of MAS and those who rejected it for forcing their candidacies through the judicial route - and the denunciations of fraud by the OAS and the opposition parties. With no room for manoeuvre, the presidential formula was forced to resign a month later at the request made by the armed forces and other actors, such as the Central Obrera Bolivia (COB), paradoxically, related to MAS.

Jeanine Áñez, opposition senator for UD, occupied the presidency on an interim basis, after the resignations of the president of the senate and the first vice president of the chamber of deputies, with the task of calling elections again. In her brief stay, she sought to openly differentiate himself from the principles, postulates and political partners held 
by the Bolivian foreign ministry between 2006 and 2019 (ministry of foreign affairs of Bolivia, 2020). In general, she ordered a diplomacy of "reversal", which was manifested in actions such as the withdrawal of Bolivia from ALBA and UNASUR; the open questioning of Venezuela, Cuba, and Iran; the request for membership of the Lima Group ${ }^{14}$ and the existence of winks for the recomposition of the relationship with the US. Nor did she appeal to the Latin American approach - typical of MAS - by vehemently criticizing the accompaniment and protection of Morales and members of his cabinet by the governments of Argentina and Mexico ${ }^{15}$.

The instability of the national scenario and the impacts of Covid-19 were delaying the holding of the presidential elections, which finally took place on October 18, 2020. With $55.11 \%$ of the votes, MAS returned to the Bolivian executive by the hand of two actors already known to the citizens: Luis Arce, minister of economy during the Morales administration and David Choquehuanca, in charge of the country's foreign relations until 2017 (Ceppi and Martínez, 2020).

The short time that has elapsed since the beginning of the new government allows, now, to make only some projections about the future of Bolivian foreign policy and diplomacy. From the government plan presented by Arce and Choquehuanca, it is inferred that foreign policy will show lines of continuity with respect to that implemented by Morales in terms of objectives and sustained postulates. Consequently, the rights of indigenous peoples, the defense of water and the coca leaf, the processes of integration and the maintenance of links with a focus on solidarity and cooperation, confirm, among others, the issues around which diplomacy must be put into action. "Bolivia's foreign policy has managed to place its own approaches on the international agenda (...) Its actions have been based on the Diplomacy of the Peoples for Life, which constitutes a vision of sovereign, proactive international relations with social participation (...) proposing initiatives of global interest, in the struggle for a culture of life and peace, to Live Well, and an international framework of solidarity, complementarity and strategic alliances capable of contributing to the development of the country" (MAS-IPSP Government Program, 2020: 45). Bolivia's return to ALBA-TCP, UNASUR and CELAC and the reestablishment of relations with Iran and Venezuela - suspended by Áñez - show that diplomacy would also be repeating the pattern of Morales' efforts.

However, it is important to consider that neither the actors nor the context (national, regional, and international) are the same as in the period 2006-2019. Arce must overcome multiple challenges both at the domestic level - reactivation of the economy, social conflict, pandemic - and in the external agenda. His statements have emphasized dialogue and consensus; elements that, it is assumed, would be the compass of the country's international action, which would contribute to lowering the profile of opposition and reactivity in the face of situations of dissent. In short, it is inferred, considering the first measures of the current president in this brief period of management and the

14 This multilateral space Arose in 2017 to monitor the Venezuelan crisis, seeking to obtain a peaceful and negotiated solution, in clear opposition to the actions of Nicolás Maduro. The Lima Declaration was signed by Argentina, Brazil, Canada, Chile, Colombia, Costa Rica, Guatemala, Honduras, Panama, Paraguay, Peru, and Venezuela (opposition). Bolivia joined during Jeanine's interin government Áñez resigned after the return of the MAS.

15 Mexico granted political asylum, while in Argentina refugee status was processed. 
difficulties of the complex scenario created by Covid-19, that Bolivian diplomacy will oscillate between marches and countermarches.

\section{References}

Arredondo, R. (2016). Derecho Diplomático y Consular. Abeledo Perrot, 220.

Asamblea General de Naciones Unidas (2009). Observaciones del Presidente de la Asamblea General de las Naciones Unidas sobre la proclamación del Día Internacional de la Madre Tierra, 22 de abril [Accessed on: 13/12/2020] Available at https://www.un.org/es/ga/president/63/statements/pga_proclam_motherearthday_apr il222009.shtml

Busso, A., Actis, E., Lorenzini, M. E., Zelicovich, J., Fernández Alonso, J., Simonoff, A. \& Calderón, E. (2016). Modelos de desarrollo e inserción internacional: aportes para el análisis de la política exterior argentina desde la redemocratización 1983-2011.

Busso, A. (2019). El vínculo entre los condicionantes internos y la política exterior. Reflexiones sobre el caso argentino. Ciclos en la Historia, la Economía y la Sociedad, (52), 3-32.

Canelas, M., \& Verdes, F. (2011). La nueva política exterior boliviana (2005-2010): más autonomía y nuevos desafíos. Ahora es cuándo, carajo, 239-266.

CELAG (2019). ¿Qué sería de Bolivia sin su política de nacionalizaciones? Unidad Debates Económicos. La Paz [Accessed on: 15/11/2020] Available at https://www.celag.org/wpcontent/uploads/2019/05/Informe-CELAG_Que-sería-de-Bolivia-sin-su-política-denacionalizaciones.pdf Ceppi, N. (2015). "Bolivia, el camino a la transformación: un proceso de cambios, conflictos y tensiones sin resolver". Leiras, S. (2017). América del Sur en los comienzos del nuevo milenio: entre la continuidad y el cambio. Eudeba.

Ceppi, N. (2019). Bolivia y Chile ante la CIJ: punto final a la judicialización del reclamo marítimo.

Ceppi, N., \& Martínez, C. (2020). Bolivia: todo pasa, todo llega, todo acaba.: Las elecciones presidenciales de 2020. El regreso del MAS. Perspectivas Revista de Ciencias Sociales, (10), 63-75.

Correa Vera, L., \& García Pinzón, V. (2013). Turbulencias desde el mar: Chile y Bolivia. Si somos americanos, 13(1), 93-121.

Decreto Supremo 28.701 (2006). 1 de mayo. Héroes del Chaco. Gaceta Oficial del Estado Plurinacional de Bolivia.

Diamint, R. (2013). Regionalismo y posicionamiento suramericano: UNASUR y ALBA/Regionalism and South American orientation: UNASUR and ALBA. Revista CIDOB d'afers internacionals, 55-79.

Exeni, J. L. (2016). Democracia (im)pactada. Coaliciones políticas en Bolivia 1985-2003. La Paz: Plural Editores.

Fernández, G. S. (2011). "Continuidad y cambios en las relaciones exteriores de Bolivia". Decursos. Revista de Ciencias Sociales, Año XIII, (23) 115-140. 
Gobierno de Perú (2019). Comunicado del Gobierno de Perú. Declaración de Ilo [Accessed on: 21/01/2021] Available at https://www.gob.pe/institucion/rree/noticias/29777declaracion-de-ilo

González Vega, J. A. (2019). En busca del esquivo mar: la controversia Bolivia-Chile ante la Corte Internacional de Justicia. En busca del esquivo mar: la controversia Bolivia-Chile ante la Corte Internacional de Justicia, 75-99.

Hedrich, M. (2016). Bolivia y China: oportunidades y riesgos de una relación desequilibrada, Diálogo Político [Accessed on: 17/08/2021] Available at https://dialogopolitico.org/actualidad/bolivia-y-china-oportunidades-y-riesgos-de-unarelacion-desequilibrada/

Hermann, C. F. (1990). Changing course: when governments choose to redirect foreign policy. International Studies Quarterly, 34(1), 3-21.

Hocking, B. (2016). "Diplomacy and Foreign Policy". Constantinou, C. M., Kerr, P., \& Sharp, P. (Eds.). (2016). The SAGE handbook of diplomacy. Sage.

International Court of Justice (2013). Application Instituting Proceedings. Obligation to negotiate access to the Pacific Ocean (Bolivia $v$. Chile), 24 de april [Accessed on: 11/09/2019] Available at https://www.icj-cij.org/files/case-related/153/17338.pdf.

International Court of Justice (2018). Obligation to Negotiate Access to the Pacific Ocean (Bolivia v. Chile). Summary of the Judgment, 1 de october. [Accessed on: 11/09/2019] Available at https://www.icj-cij.org/files/case-related/153/153-20181001-SUM-01-00EN.pdf

Justo, J. B. (2013). El derecho humano al agua y al saneamiento frente a los Objetivos de Desarrollo del Milenio (ODM).

Lasagna, M. (1995). Las determinantes internas de la política exterior: un tema descuidado en la teoría de la política exterior. Estudios Internacionales, 387-409.

Lasagna, M. (1996). Cambio institucional y política exterior: un modelo explicativo. Revista CIDOB d'afers internacionals, 45-64.

Lechín, D. A. (2015). "Bolivia mira hacia el sur. El ingreso al Mercosur y la política exterior de Evo Morales". Nueva Sociedad, (259), 15.

Martínez, C. B. (2016). El vivir bien en el proyecto político del MAS en Bolivia (20062015) (Bachelor's thesis, Facultad de Ciencia Política y Relaciones Internacionales).

Mayorga, F. (2008). "El gobierno de Evo Morales: cambio político y transición estatal en Bolivia". En Murakami, Y. (Ed.). (2008). Tendencias políticas actuales en los países andinos ( $p p .41-63$ ). CIAS, Center for Integrated Area Studies, Kyoto University.

Mayorga, F. (2016). Bolivia: ciclo electoral 2014-2015 y mutaciones en el campo político. Elecciones y legitimidad democrática en América Latina, 205-234.

Míguez, M. C. (2017). La política exterior del primer año del gobierno de Mauricio Macri: ¿Situación instrumental del Estado?. Revista Estado y Políticas Públicas, (8), 103-120.

Míguez, M. C. (2020). "Los factores internos de la política exterior. Hacia la profundización de un debate en las Relaciones Internacionales latinomericanas". En 
Míguez, M. C. y Morgenfeld, L. (2020) Los condicionantes internos de la política exterior: entramados de las relaciones internacionales y transnacionales. Buenos Aires: TeseoPress, 21-74.

Milani, C. R., \& Pinheiro, L. (2013). Política externa brasileira: os desafios de sua caracterização como política pública. Contexto internacional, 35, 11-41.

Ministerio de Economía y Finanzas Públicas de Bolivia (2019). Memoria de la economía boliviana 2018. La Paz.

Ministerio de Relaciones Exteriores del Estado Plurinacional de Bolivia (2014). La revolución democrática y cultural y su política exterior. Memoria 2006-2013. La Paz [Accessed on: 13/09/2020] Available at https://www.cancilleria.gob.bo/webmre/sites/default/files/Logros/1\%20Memoria\%20In stitucional\%202006-2013\%20\%281\%29.pdf

Ministerio de Relaciones Exteriores del Estado Plurinacional de Bolivia (2020). Memoria institucional 2019-2020 [Accessed on: 11/01/2021] Available at https://www.cancilleria.gob.bo/webmre/node/4038

Morales, Evo (2006). Discurso del Presidente de Bolivia en la Asamblea General de Naciones Unidas [Accessed on: 13/01/2019] Available at https://digitallibrary.un.org/record/583259? In=es

Pino, I. M. (2001). La Diplomacia. Aspectos teóricos y prácticos de su ejercicio profesional. México: SER-FCE.

Namihas, S. (2013). La demanda boliviana contra Chile ante la Corte Internacional de Justicia de La Haya. Agenda Internacional, 20(31), 55-70.

Olmos, P. (2014). La construcción de un "nos-otros" en los relatos de Evo Morales ante la organización de las Naciones Unidas. Perspectivas de la Comunicación, 7(2), 75-95.

Oszlak, O. y O’Donnell, G. (1976). Estado y políticas estatales en América Latina: hacia una estrategia de investigación. Documento CEDES-CLACSO, (4), Buenos Aires.

Pérez, A. M. (1989). La diplomacia. Orientación vocacional y profesional. México: Universidad Nacional Autónoma de México.

Plan Nacional de Desarrollo (2006). Bolivia Digna, Soberana, Productiva y Democrática para Vivir Bien: Lineamientos Estratégicos", 2006-2011. Gaceta Oficial de Bolivia, Decreto Supremo 29.272, La Paz [Accessed on: 11/08/2020] Available at http://www.ademaf.gob.bo/normas/ds29272.pdf.

Ponce, S. C. (2012). Estados plurinacionales en Bolivia y Ecuador: Nuevas ciudadanías, ¿más democracia?. Nueva Sociedad, (240), 134.

Ponce Costas, V. L. (2020) La política exterior de Bolivia en el marco del proceso de integración de UNASUR en el gobierno de Evo Morales Ayma (PhD thesis). [Accessed on: 13/08/2021] Available at https://repositorio.umsa.bo/handle/123456789/25814

Programa de gobierno MAS-IPSP (2005). Por una Bolivia Digna, Soberana y Productiva para Vivir Bien [Accessed on: 13/12/2020] Available at http://www.archivochile.com/Portada/bol_elecciones05/bolelecciones0009.pdf 
Programa de gobierno MAS-IPSP (2020). Agenda del Pueblo para el Bicentenario y el

Vivir Bien [Accessed on: 03/01/2021] Available at http://www.protagonistas.cm.org.bo/archivos/programas/Programa_Gobierno_MASIPSP_EG_2020.pdf

Querejazu Escobari, A. (2015). "Indigenidad" in Bolivia's Foreign Policy During Evo Morales' Government. Desafíos, 27(1), 159-184.

Roberto, H. S., Carlos, F. C., \& Pilar, B. L. (2014). Metodología de la investigación 6ta Edición. DR-D.-D. Lucio, Metodologia de la Investigacion Mexico DF: McGRAWHILL/INTERAMERICANA EDITORES, SA DE CV. (6)

Ruth, S. (2005). Todo es Teoría; Objetivos y métodos de investigación. Bs. As.: Lumiere. Sanahuja, J. A. (2012). "Regionalismo post-liberal y multilateralismo en Sudamérica: El caso de UNASUR". En Serbín, A., Laneydi M., y Ramanzini Júnior, H. (2012), El regionalismo "post-liberal" en América Latina y el Caribe: Nuevos actores, nuevos temas, nuevos desafíos. Buenos Aires: CRIES, pp. 19-72.

Souza, A. L. C. F. D., Cunha, C. M., \& Santos, V. (2020). Changes in the Foreign Policy of Bolivia and Ecuador: Domestic and International Conditions. Brazilian Political Science Review, 14.

Svampa, M. N. (2017). Cuatro claves para leer América Latina. Nueva sociedad.

Svampa, M. (2019). Las fronteras del neoextractivismo en América Latina: conflictos socioambientales, giro ecoterritorial y nuevas dependencias (p. 144), Alemania: Bielefeld Press Univesity.

Tamayo Sáez, M. (1997). "Análisis de las políticas públicas". En Bañón, R., Carrillo E. (1997). La nueva administración pública. Madrid: Alianza Editorial, pp. 281-312.

Taylor, S. J., \& Bogdan, R. (1987). Introducción a los métodos cualitativos de investigación (Vol. 1). Barcelona: Paidós.

Rosero, L. F. T. (2013). Ejes Articuladores del Discurso Internacional del Presidente del Estado Plurinacional de Bolivia Evo Morales Ayma. Encrucijada Americana, 5(2), 43-53.

Veiga, P. D. M., \& Rios, S. P. (2007). O regionalismo pós-liberal, na América do Sul: origens, iniciativas e dilemas. Cepal.

Vergara Toro, M. A. (2016). Evolución de la cooperación de Venezuela con Ecuador y Bolivia en el periodo 2006-2014 (Master's thesis, Universidad Andina Simón Bolívar, Sede Ecuador).

Pintos, E. V. (2016). Curso de Derecho Diplomático y Consular. Madrid: Editorial Tecnos, Quinta Edición.

Von Wolff, M. W. (1991). Los objetivos en la política exterior Latinoamericana. Estudios Internacionales, 176-193.

Zuazo, M. (2010). Los movimientos sociales em el poder?. Revista Nueva Sociedad, (227). 